\title{
European Union research finds Scandinavian model
}

Munich. Jorma Routti, president of the Finnish innovation agency, SITRA, was this month formally appointed director general of the European Commission's research directorate, although he will not move from Helsinki to Brussels until the autumn.

Routti's first task will be to oversee six new technology development programmes - in vaccines for viral diseases, educational software and multimedia, integrated transport systems and the next generation of cars, trains and aircraft. These are being prepared by joint task forces, which Edith Cresson, the research commissioner, created earlier this year with the industry and transport directorates (see Nature 374, 206; 1995).

The task forces have been criticized for giving industry a greater role in deciding research policy - the commission has a poor track record in picking industrial winners. Some commission officials also believe the programmes will be too complex to administer. Many are also concerned that Cresson may divert the ECU700 million (US\$924 million) held in reserve for the next Framework programme from science programmes into pilot programmes suggested by the task forces. According to one commission official, the money will probably be divided between the pilot programmes, international cooperation - particularly with eastern Europe and some oversubscribed programmes within the fourth Framework.

Nonetheless, Routti, who claims to be a staunch defender of basic research, enthusiastically supports the task forces, which he says have different goals from those of the Framework research programmes. Entering new high-technology markets and competing internationally require both flexible structures and combining the resources of the

research commission with those of other commissions, he says.

One key issue is whether the joint development programmes will be funded within the fifth Framework programme, a draft of which must be submitted to the European Parliament in 1997. Routti says he has not yet had time to consider the issue, but that basic research must be defended within

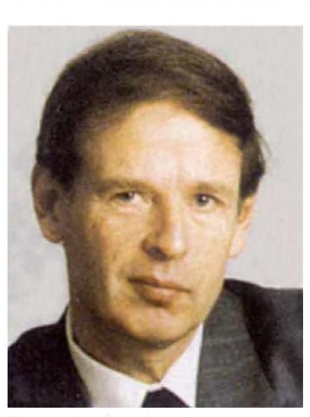

Routtl:"fiexible research structures needed".
Framework programmes. "Science and research should not be harnessed to pull the wagon of industry," he says. "Their economic potential needs to be safeguarded."

Routti's belief in a strong basic research base combined with efficient technology transfer is based on his experience in Finland. Forestry-related industries accounted for most Finnish exports up until the 1960 s, but high-technology products now make up one-fifth. The continued strength of the forestry and related industries in world markets, he says, is a result of investment in research over the last two decades.

Routti, who is 56 , has a background in physics and technology management. $\mathrm{He}$ became president of SITRA in 1986 and was responsible for reorganizing the agency, which promotes technology transfer by cofinancing a system of cooperation networks between universities, venture capitalists and industry. SITRA has been instrumental in bringing about the acknowledged success of Finland in high technology. Alison Abbott

\section{EU rejects reshuffling renewables}

Munich. The European Commission has dismissed as "absolutely untrue" allegations by the European Parliament's Green group that it diverted funds destined for renewable energy into other non-nuclear energy research.

Renewable energy should receive 62 per cent of the ECU967-million (US\$1.3-billion) funds from the five-year Joule non-nuclear energy programme. But of the ECU191 million distributed in the first round of grants in July, it received just 40 per cent.

One reason why suspicions of manipulation of funds have been aroused, the commission concedes, is that some applicants for renewable research projects had been told informally but incorrectly that their applica- tions would be successful.

The commission claims the 62 per cent target was not met in the first funding round because "there were simply not enough good renewable energy projects. One hundred and seventy-six projects were chosen from 936 applications, on the basis of merit," says one official, who claims that the balance will be adjusted in subsequent rounds.

Proposals for renewable energy research tend to come from small companies and research groups that lack experience in preparing applications, he argues, adding that the commission now intends to coach such applicants, in a bid eventually to meet the 62 per cent target.

Alison Abbott

\section{Japanese take first steps towards gene therapy trials}

Tokyo. Japan's first application of gene therapy emerged from a long process of approval this month when researchers at Hokkaido University Hospital reintroduced lymph cells to a four-year old-boy suffering from adenosine deaminase deficiency, a rare enzyme deficiency that depresses the immune system.

Using a technique developed by the US National Institutes of Health in 1990, the lymph cells, extracted a week earlier from the boy, had been treated with a vector to introduce genes producing the deficient enzyme. The treatment will need to be repeated at monthly intervals, and the outcome will not be known for several months. Coming after a lengthy approval, this first gene therapy trial has obtained wide coverage in the Japanese media.

David Swinbanks

\section{Murder charges brought in German HIV blood products case}

Munich. Two officials of Haemoplas, a German blood products company, have been charged with murder for allegedly selling blood products not tested for HIV.

If convicted, Frank Giesbert, the director of the company - which is based in Osterode in the state (Land) of Niedersachsen - and Günter Eckert, the head of its blood product testing laboratory, face life imprisonment.

Laws testing blood products have been tightened following allegations last year that the Koblenz-based company UB Plasma pooled blood donations before testing for HIV, and visually assessed the colorimetric results. Three customers were infected with HIV, and one has died of AIDS. Five officials were charged with grievous bodily harm, which carries a maximum five-year prison sentence.

Giesbert and Eckert have been charged with murder on the grounds that they had been motivated by greed. They are alleged to have conspired in the early 1980s to economize by not testing blood samples, and to have persisted after testing was made compulsory in 1985.

Fourteen people became infected with HIV through Haemoplas products between 1986 and 1987 , and three have since died.

Both men have also been charged with 5,837 counts of attempted murder corresponding to the number of batches distributed - infringing legislation on the control of pharmaceutical products, and fraud.

Alison Abbott 